\title{
Multilocular cystic clear cell renal cell carcinoma imaging with histopathologic correlation
}

\author{
Emi Marinela Preda ${ }^{1,3}$, loana Gabriela Lupescu ${ }^{1,3}$, Adrian Dijmarescu ${ }^{3}$, Gelu A. Popa ${ }^{1,3}$, \\ Mugur C. Grasu ${ }^{1,3}$, Monica Hortopan ${ }^{2}$
}

${ }^{1}$ Radiology, Medical Imaging and Interventional Radiology Department, Fundeni Clinical Institute, Bucharest, Romania 2Department of Pathologic Anatomy, Fundeni Clinical Institute, Bucharest, Romania ${ }^{3}$ University of Medicine and Pharmacy «Carol Davila», Bucharest, Romania

\section{ABSTRACT}

Renal cell carcinoma (RCC) causes significant morbidity and mortality. Clear cell RCC (ccRCC) is the most common histologic subtype, with worse prognosis compared with other histologic subtypes. The indolent variant of CCRCC is the multilocular cystic RCC (McRCC). Imaging features reflect the various histological findings of each histologic subtypes. Recent advances in imaging technology permit early and more appropriate diagnosis of RCC and facilitate optimal management.

Key words: Multilocular cystic clear cell renal cell carcinoma, renal cell carcinoma, clear cell renal carcinoma, imaging, CT, MRI

\section{INTRODUCTION}

Renal cell carcinoma ( $R C C$ ) is the most common adult renal epithelial cancer, accounting for more than $90 \%$ of all renal malignancies and is the most lethal of all urologic cancers $(1,2)$. The most of the cases are diagnosed incidentally during imaging examinations (2-6). In 2004 World Health Organization reviewing renal neoplasms classification, recognizes several distinct histologic subtypes of RCC. Clear cell RCC is the most common subtype and has a less favorable prognosis than papillary RCC and chromophobe RCC. Multilocular cystic RCC is a distinct subtype of clear-cell RCC that appears to have a favorable prognosis. We report a case of McRCC, which is a rare entity, comprising approximately 1 to $2 \%$ of all renal tumors and approximately $4 \%$ of all ccRCC (although the truth is unknown due to the lack of this subtype before 2004) $(3,4,5)$

\section{CASE REPORT}

Our patient is a men, 65 years old, Known with type II diabetes mellitus in treatment with oral medication, treated hypertension, BRD, prostatic hypertrophy, hospitalized in the Urology Department of Fundeni Clinical Institute,
Corresponding author:

loana G.Lupescu, MD

Radiology and Medical Imaging

Department, Fundeni Clinical Institute

258 Fundeni Str., Sector 2, 022328

Bucharest, Romania

E-mail: ilupescu@gmail.com emimpreda@gmail.com 
in order for investigations and treatment for a large right renal cyst diagnosed by ultrasound.

Clinically, the patient had at admission: good general condition, no fever, diuresis present, clear urine and about $10 \mathrm{~cm}$ mobile, palpable tumor in right kidney lodge.

Urinary tract ultrasound demonstrated a normal left kidney, half-filled bladder, prostate volume $=24$ cc; right kidney with $111 \mathrm{~mm}$ cyst of posterior valve, with multiple septa. It is recommended computed tomography examination with iodinated non-ionic contrast.

Computed tomography (CT) revealed a voluminous, well-defined, extrarenal cystic mass (dimensions: 11/8 $\mathrm{cm}$ ) with predominant fluid component, containing one small expansile dense nodule (about $18 / 13 \mathrm{~mm}$ ), with intense enhancement, located just above of some enhanced septa - aspects that are characteristics for a Bosniak cyst type IV. (figure 1). Left kidney with normal CT aspect.
Magnetic Resonance (MR) examination performed in conjunction with $\mathrm{CT}$ examination noted expansive mass found in the right kidney with extrarenal development predominantly, having the same dimensions described at $\mathrm{CT}$, with predominant cystic component manifesting water restriction on diffusion sequence and containing a small solid nodule with strong enhancement, located on the anterior wall and several enhancing, irregular septa, which gives a multilocular appearance - features that suggests malignant cystic lesion, requiring surgical resection. MR conclusion was: multilocular right renal cystic tumor. (figure 2)

After clinical evaluation and preliminary lab tests is decided on 04.08 .2015 , radical nephrectomy through the lumbar approach, with favorable postoperative evolution

Histopathological parameters were put into evidence after histological preparation with H\&E staining: cystic tumor formation with exophytic development in right kidney parenchyma (max. 12/9
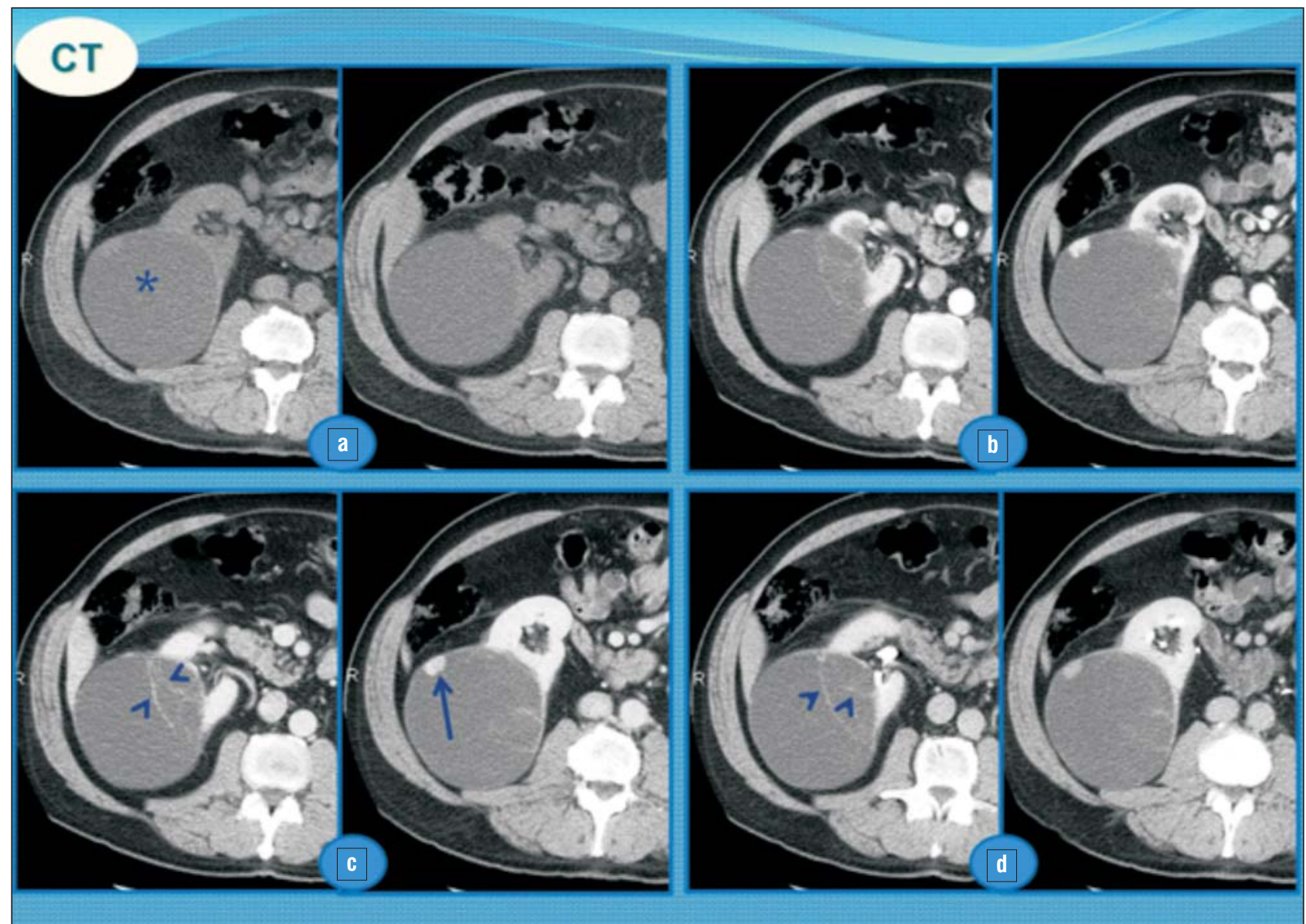

Figure 1 - CT exam [nonenhanced - (a) and after intravenous contrast admnistration in cortico-medullary - (b), nephrographic - (c) and delay, parenchymal phase - (d)]: voluminous, well-defined, extrarenal cystic mass with predominant fluid component ( ${ }^{*}$ ), containing an expansive small dense nodule (arrow), with intense iodinate enhancement, located just above of some enhanced septa (arrowhead) 


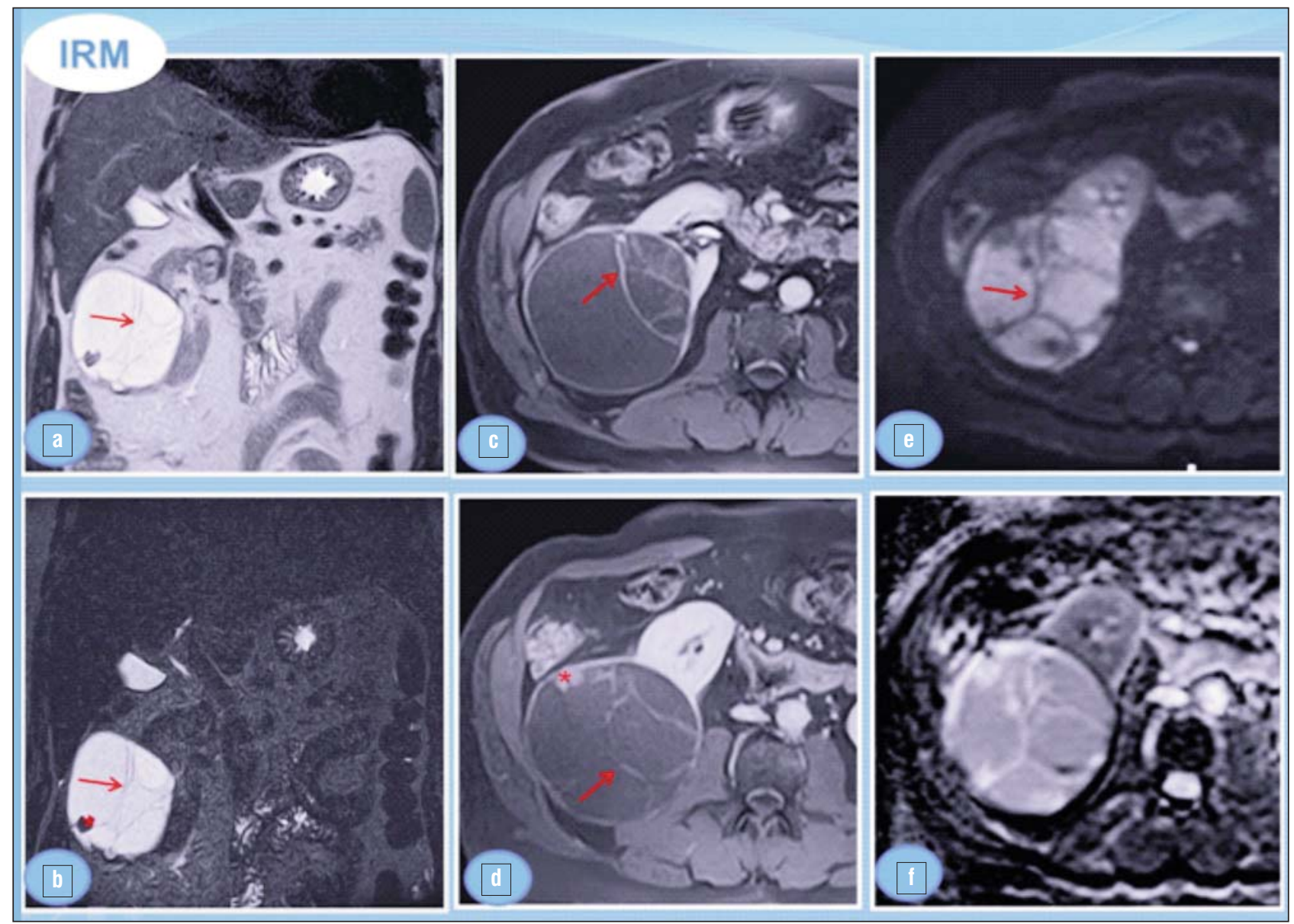

Figure 2 - MR exam shows an expansive right kidney cystic mass with a predominant fluid component [better assessed on (a) - short TE SS FSE and (b) - long TE SS FSE acquistions] containing a small solid nodule $\left(^{*}\right)$, that enhance strongly [after intravenous gsadolinium admnistration - (c, d)] and several enhancing, irregular septa, which gives a multilocular appearance (arrow). Note water restriction of the fluid content on the diffusion weighted sequence (e and $f$ )

$\mathrm{cm})$, with a multilocular pattern, polymorph, polychromatic areas with intraseptal solid aspect. The histopathological aspect suggest a renal cell carcinoma - clear cell type, Fuhrman nuclear grade 2, multilocular cystic pattern, richly vascularized, with foci of intratumoral bleeding. The proliferation of renal tumor evolves out of the well defined outline of a conjunctivecollagen pseudo-capsule lamellar without invasive aspects. (figure 3). Renal capsule, vessels, and perinephric fat were free.

The histopathological conclusions where: multilocular cystic clear cell carcinoma clear, Fuhrman nuclear grade 2 .

\section{DISCUSSION}

With the increasing availability of imaging and methods becoming more efficient, it increased the number of incidentally detected renal tumors in small stages (asymptomatic). Ultrasound (US) is "guilty" for most of incidental "discovered" renal masses.

Computed Tomography (CT) is considered the main method for renal cystic lesions characterization (6), allowing accurate measurement of both fluid attenuation values (0-2OHU), but also of fatty, solid or calcified components. Also, CT underpinned the foundations of Bosniak classification, widely embraced by radiologists and urologists. That CT-based renal cyst classification system, proposed in 1986 and modified by Bosniak in 1993, provides a guide for further imaging evaluation or intervention (7).

In its actual form, cysts are classified into four categories, different from the point of view of management: category I (simple renal cysts ), category II (benign renal cysts, that are minimally complicated, but not in need of surgery), category III (more complicated cystic lesions, potentially malignant, in need of surgery) and category IV (clearly malignant cystic carcinomas). The classification revised in 1993 include a subset of minimally complicated lesions (category IIF), lesions that 


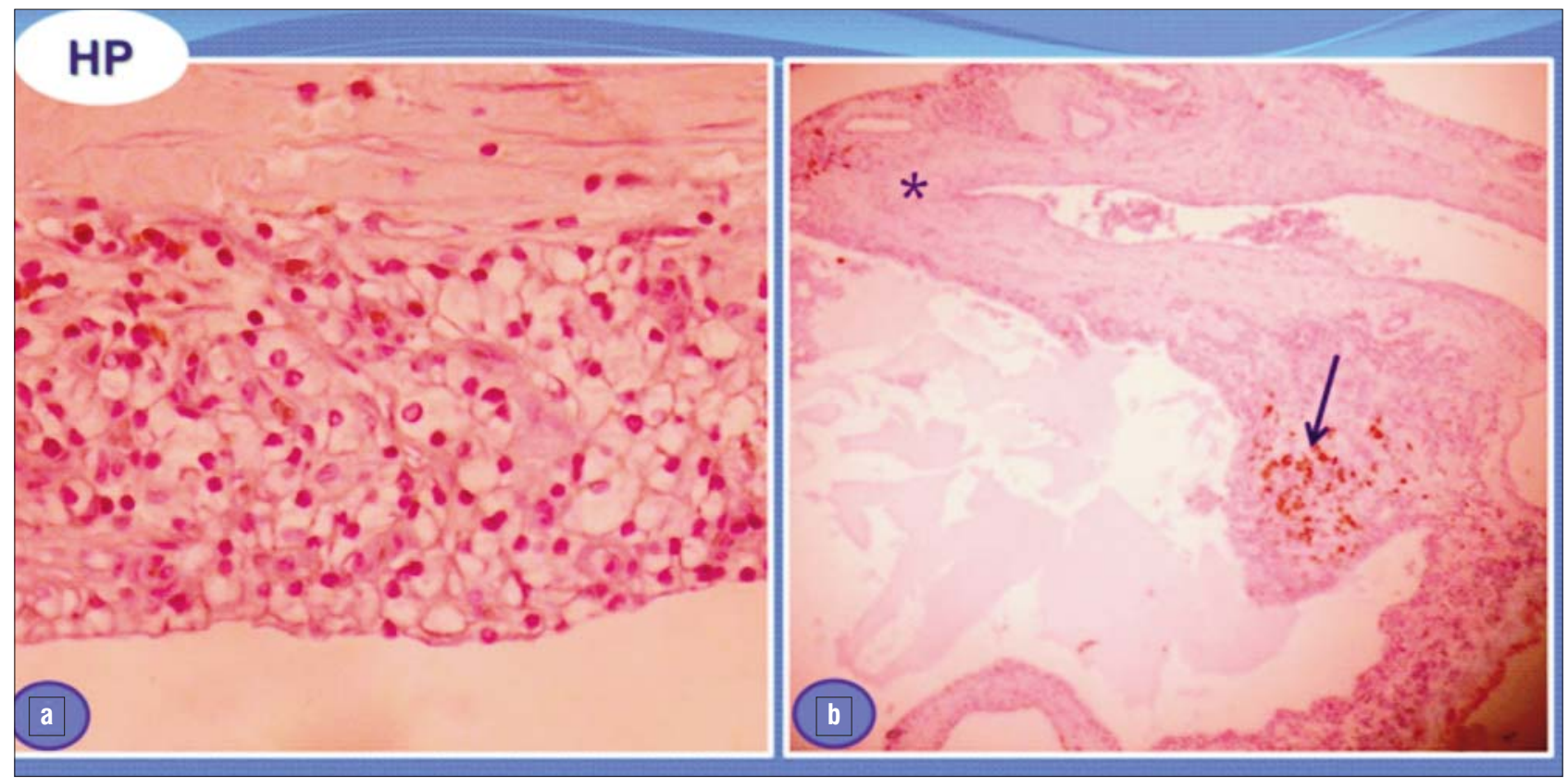

Figure 3 - Photomicrograph of histologic section (H and E, X200) shows: (a) typical histologic appearance of clear cell renal cell carcinoma, showing epithelial cells with clear cytoplasm and a distinct cell membrane, separated by a fine branching network of vascular tissue. (b) clear cell epithelial lining with fluid-filled lumen, small polypoid projection into lumen with foci of intratumoral bleeding (arrow); also note dense fibrous component $\left({ }^{*}\right)$

Tabel 1 - The Bosniak Renal Cyst Classification System

\begin{tabular}{|c|c|}
\hline Category & Criteria and Management \\
\hline benign simple cyst & $\begin{array}{l}\text { - hairline-thin wall; does not contain septa, calcifications, or solid components; water attenuation / fluid signal and } \\
\text { does not enhance; } \\
\text { - no intervention, no follow-up is needed }\end{array}$ \\
\hline $\begin{array}{l}\text { benign cystic lesions } \\
\text { minimally complicated }\end{array}$ & $\begin{array}{l}\text { may contain a few hairline-thin septa in which perceived (not measurable) enhancement may be appreciated; } \\
\text { fine calcification may be present in the wall or septa; } \\
\text { - uniformly high-attenuating lesions that are sharply marginated and do not enhance are included in this group; } \\
\text { - }<3 \mathrm{~cm} \text { in diameter } \\
\text { - no intervention, no follow-up is needed }\end{array}$ \\
\hline $\begin{array}{l}\text { minimally complicated } \\
\text { lesions that could be } \\
\text { managed with follow-up }\end{array}$ & $\begin{array}{l}\text { - may contain multiple hairline-thin septa; perceived (not measurable) enhancement of a hairline-thin smooth } \\
\text { - there may be minimal thickening of wall or septa, which may contain calcification that may be thick and nodular, } \\
\text { but no measurable contrast enhancement is present; there are no enhancing soft-tissue components; } \\
\text { - totally intrarenal nonenhancing high-attenuating renal lesions }(>3 \mathrm{~cm}) \text { are also included in this category; } \\
\text { - generally well marginated; }\end{array}$ \\
\hline Iili & - with thickened irregular or smooth walls or septa and in which measurable enhancement is present; \\
\hline more complicated cystic & $\begin{array}{l}\text { - this category includes complicated hemorrhagic or infected cysts, multilocular cystic nephroma, and cystic } \\
\text { neoplasms; } \\
\text { - need surgical intervention in most cases, as neoplasm cannot be excluded; } \\
\text { - need histologic diagnosis, as even gross observation by the urologist at surgery or the pathologist at gross } \\
\text { pathologic evaluation is frequently indeterminate }\end{array}$ \\
\hline $\begin{array}{l}\text { clearly malignant } \\
\text { cystic carcinomas }\end{array}$ & $\begin{array}{l}\text { - can have all of the criteria of category III but also contain distinct enhancing soft-tissue components } \\
\text { - need to be removed }\end{array}$ \\
\hline
\end{tabular}

are more complex than a category II cyst but are still thought to be benign and require only serial imaging to confirm stability $(8,9)$ (table 1$)$.

MR Imaging (MRI) is helpful when renal lesions are detected by others imaging methods but not so well characterized. MRI is offering greater details in complicated renal cysts, with septa and solid nodules or in multilocular cystic lesions (7). Multiplanar MRI acquisitions 
are very important in cystic renal masses evaluation, because the imaging planes of the sequences may be modified to best depict the mass $(10,11)$.

Multilocular cystic RCC cannot be always differentiated from other complex cystic renal lesions on images. As the name suggests, multilocular cystic RCC is a multiseptated cystic RCC whose septa contain small clusters of clear cells. In these cases, the CT or MR appearances can range from a Bosniak IIF cyst to a Bosniak IV cystic lesion. Multilocular cystic RCCs typically manifest as multilocular cystic tumors, variable-sized, separated from the kidney by a fibrous capsule. Microscopic examination of the surgically resected tissue is often necessary for a diagnosis of certain $(3,12,13)$.

Diffusion-weighted imaging (DWI) is a new technique for renal masses, providing quantification of the Brownian motion of water molecules in tissues, which depends on tissue organization, cellularity, the integrity of cell membranes, and extracellular space tortuosity (14). Qualitative and quantitative information are obtained regarding tissue characterization without the need for Gadolinium administration. Several authors (Goyal, Taouli and Wang) showed that the mean ADC value of clear cell RCC was found to be significantly higher than that of non-clear cell RCC, while Sandrasegaran did not find any significant difference in the ADC values of clear cell RCCs and non-clear cell malignancies $(15,16,17,18)$.

Histopathological analysis demonstrates cysts lined by a monolayer of epithelial cells with clear cytoplasm (13).

Multilocular cystic renal cell carcinoma is distinguished from the other subtypes of RCC based on the high incidence of stage I disease at initial presentation ( $83 \%$ to $88 \%)$, infrequent metastases, and an extremely high cure rate following surgical resection of the tumor $(19,20)$.

\section{CONCLUSION}

Histology of clear cell RCC is reflected in advanced imaging characteristics. Accurate imaging and histologic characterization of RCC and its subtypes (ie multilocular cystic RCC) are very important for the proper management of the patient and its prognostic.

\section{Acknowledgement}

This work received financial support through the project entitled „CERO - Career profile: Romanian Researcher", grant number POSDRU/159/1.5/S/135760, co-financed by the European Social Fund for Sectorial Operational Programme Human Resources Development 2007-2013.

\section{REFERENCES}

1. Eble $\mathrm{JN}$, Sauter $\mathrm{G}$ et al, Pathology and genetics of urinary systemand male genital organs, Lyon, France, IARC Press, 2004

2. Jemal A, Tiwari RC, Murray T, Ghafoor A, Samuels A, Ward E, et al, Cancer statistics, 2004. CA Cancer J Clin. 2004 Jan-Feb;54(1):8-29.

3. Hindman NM, Bosniak MA, Rosenkrantz AB, Lee-Felker S, Melamed J. Multilocular cystic renal cell carcinoma: comparison of imaging and pathologic findings. AJR Am J Roentgenol. 2012 Jan;198(1):W20-6.

4. Murad T, Komaiko W, Oyasu R, Bauer K. Multilocular cystic renal cell carcinoma. Am J Clin Pathol. 1991 May;95(5):633-7.

5. Corica FA, Iczkowski KA, Cheng L, Zincke H, Blute ML, Wendel A, et al. Cystic renal cell carcinoma is cured by resection: a study of 24 cases with long-term followup. J Urol. 1999 Feb;161(2):408-11.

6. Hartman DS, Choyke PL, Hartman MS. From the RSNA refresher courses: a practical approach to the cystic renal mass. Radiographics. 2004 0ct;24 Suppl 1:S101-15.

7. Preda Emi Marinela, Popa G.A., Lupescu loana G. What's old, new and especially helpful in cystic renal masses imaging diagnosis?, ECR 2015, http://dx.doi.org/10.1594/ecr2015/C-2419

8. Bosniak MA. Diagnosis and management of patients with complicated cystic lesions of the kidney. AJR Am J Roentgenol. 1997 Sep;169(3):81921.

9. Hwang JH, Lee CK, Yu HS, Cho KS, Choi YD, Ham WS. Clinical Outcomes of Bosniak Category IIF Complex Renal Cysts in Korean Patients. Korean J Urol. 2012 Jun;53(6):386-90.

10. Israel GM, Bosniak MA. How I do it: evaluating renal masses. Radiology. 2005 Aug;236(2):441-50.

11. Bosniak MA. The current radiological approach to renal cysts, Radiology. 1986 Jan;158(1):1-10.

12. Murphy WM, Grignon DJ, Perlman EJ. Tumors of the Kidney, Bladder, and Related Urinary Structures. Washington, DC: American Registry of Pathology; 2004;121-123. AFIP Atlas of Tumor Pathology; Fourth Series, Fascicle 1.

13. Prasad SR, Humphrey PA, Catena JR, Narra VR, Srigley JR, Cortez AD, et al. Common and uncommon histologic subtypes of renal cell carcinoma: imaging spectrum with pathologic correlation. Radiographics. 2006 NovDec;26(6):1795-806; discussion 1806-10.

14. Padhani AR, Liu G, Koh DM, Chenevert TL, Thoeny HC, Takahara T, et al. Diffusion-weighted magnetic resonance imaging as a cancer biomarker: consensus and recommendations. Neoplasia. 2009 Feb;11(2):102-25.

15. Goyal A, Sharma R, Bhalla AS, Gamanagatti S, Seth A, lyer VK, et al. Diffusion-weighted MRI in renal cell carcinoma: a surrogate marker for predicting nuclear grade and histological subtype. Acta Radiol. 2012 Apr 1;53(3):349-58.

16. Taouli B, Thakur RK, Mannelli L, Babb JS, Kim S, Hecht EM, et al. Renal lesions: characterization with diffusion-weighted imaging versus contrastenhanced MR imaging. Radiology. 2009 May;251(2):398-407.

17. Wang H, Cheng L, Zhang X, Wang D, Guo A, Gao Y, et al. Renal cell carcinoma: diffusion weighted MR imaging for subtype differentiation at 3.0 T. Radiology. 2010 0ct;257(1):135-43.

18. Sandrasegaran $K$, Sundaram $C P$, Ramaswamy R, Akisik FM, Rydberg MP, Lin C, Aisen AM. Usefulness of diffusion-weighted imaging in the evaluation of renal masses. AJR Am J Roentgenol. 2010 Feb;194(2):438-45.

19. Eble JN, Sauter G, Epstein Jl, et al eds. Pathology and Genetics of Tumours of the Urinary System and Male Genital Organs. Lyon, France: IARCC Press; 2004. World Health Organization Classification of Tumours.

20. Suzigan S, López-Beltran A, Montironi R, Drut R, Romero A, Hayashi T, et al. Multilocular cystic renal cell carcinoma: A report of 45 cases of a kidney tumor of low malignant potential. Am J Clin Pathol. 2006 Feb;125(2):21722. 